attention to the mangroves. A party consisting of Dr. Thomas, Mr. Philipson and Mr. Sporno is going to spend a month in the rain forest where each will carry out research on his own problems : Dr. Thomas working on the Pteridophyta, Mr. Philipson collecting, because he is one of those appointed to complete the late Dr. Rendlo's "Flora of Jamaica", and Mr. Sporno investigating flower morphology. The whole expedition will return at the beginning of October with the exception of Mr. Philipson, who will stay on for a few more months.

\section{Earthquake on the Gold Coast}

EARTH tremors shook the whole district of the Gold Coast, Ashanti, Dahomey and Western Nigeria in West Africa from about 7.10 p.m. on June 22 to 4 a.m. on June 23. It is not yet clear whether there were several shocks of approximately equal dimensions from one or several closely situated epicentres, or whether there was one large earthquake with precursors and aftershocks. With the evidence available at the moment, the latter appears to be the most probable as the greatest impact of the earthquake was felt at Accra $\left(5^{\circ} 30^{\prime} \mathrm{N} ., 0^{\circ} 10^{\prime} \mathrm{W}.\right)$, Cape Coast $\left(5^{\circ} 5^{\prime} \mathrm{N} ., 1^{\circ} 0^{\prime}\right.$ WV.), and Sekondi $\left(4^{\circ} 53^{\prime}\right.$ N., $I^{\circ} 48^{\prime}$ W.) at 7.15 p.m. on June 22 . If the intensity of the shock was the same at each of these three places, as the immediately available evidence seems to indicate, then the epicentre was near $5^{\circ} \mathrm{N} ., 1^{\circ} \mathrm{W}$. and the focus rather below normal, or it was, say, $3.5^{\circ} \mathrm{N} ., 1^{\circ} \mathrm{W}$. in the Gulf of Guinea and depth of focus normal. Further evidence from the area, but more particularly the evidence of seismograms, will decide this. Many public buildings, banks, offices and native houses in the area have been damaged or destroyed, killing seventeen people at Accra, twenty-nine at Cape Coast and twenty at Sekondi, besides injuring several others. At Accra the electric lighting system was interrupted, but this was quickly remedied. An earthquake of these dimensions is an exceptionally rare occurrence, if not unknown, near Accra, and according to recent catalogues of epicentres there is no active epicentre anywhere near the present one. It is unfortunate that there are no seismographs situated nearer the probable epicentre than Algiers, Johannesberg, Cape Town and Nairobi, though the shock appears to have been sufficiently intense to have been registered at these, and by seismographs at even greater epicentral distances.

\section{Entomological Control of Lantana}

THE rapid spread of Lantana, a garden escape, in Northern Queensland has brought it amongst the serious weed pests for which the Council for Scientific and Industrial Research, Australia, is seeking methods of control. In 1935 studies of T'eleonemia lantance were commenced in Fiji, where this bug had been introduced from Mexico, its native home, by way of Hawaii. As it proved harmless to any Australian plants of economic importance, it was established under quarantine conditions in Canberra in 1936. The first liberations were made late in that year in the Northern Rivers area of New South Wales, and afterwards near Atherton in Queensland, and at Rockhampton. Disappointment followed; the bugs seemed to have disappeared, until in April of this year they were reported in the Atherton district in enormous numbers over an area of some twenty-four acres. Leaves were falling from the Lantana bushes, flowers had been destroyed and in some instances up to two feet of the ends of branches had been killed as the result of the bug feeding on them. At Rockhampton also there are signs of establishment. Undue optimism is to be deprecated, and it is unlikely that similar success will be attained to that of Cactoblastis on prickly pear. It still remains to be seen whether Teleonemia can maintain itself in large numbers and whether continuous defoliation will destroy Lantana; nevertheless, the outlook is promising.

\section{Exhibition of New Textile Fibres}

AN exhibition of new textile fibres has been arranged at the Science Museum, South Kensington, and will be opened on July 3 for two months. To-day' fibres possessing many of the properties of natural wool are manufactured from skimmed milk. The exhibit illustrating the stages in the manufacture of casein yarn includes several examples of fabrics, woven on worsted machinery. Another group of exhibits includes yarns and materials as produced by the viscose and cellulose acetate methods. These are generally termed rayon or 'artificial silk'. By modification of the spinning processes it is now possible to manufacture exceptionally strong yarns of this material, and some of the applications are illustrated by such articles as a section of a motor tyre showing the cord reinforcement, 'doped' aeroplane fabric, fine gauge hose, sail cloth, etc. An interesting American exhibit shows a new type of cellulose acetate rayon in which the fibre is characterized by an inherent stabilized crimp, producing a yarn the behaviour of which is comparable in some respects to that of wool. One of the most important textile discoveries of recent times has been that of nylon. This is a truly synthetic yarn and is the first textile fibre prepared wholly of raw materials from the mineral kingdom. Although derived from coal, air and water, nylon can be produced in filaments of exceptional strength or as fine as a spider's web, yet having elasticity and lustre. Another striking development is to be found in the use of glass fibres. Objects showing this class of fibre include woven and knitted fabrics mado entirely of pure glass with a collection of articles indicating the commercial applications. An exhibit of interest from Tokyo shows fibre and yarn produced from seaweed. Jute, sisal, and hemp are each represented, with examples of the latest types of yarns and materials produced from these fibres.

\section{British Museum (Natural History) : Acquisitions}

RECENT acquisitions in the Department of Zoology include a collection of Northern Rhodesian mounted heads and skulls of ungulates made chiefly at Mrpika 
by the late Mr. F. H. Melland and presented by Mrs. Jelland. The collection contains some very fine sable and roan antelope heads and is of special interest in that the species represent a transition stage from the southerly types of South Africa to the more northerly forms found in Tanganyika Territory and Kenya Colony. Another interesting gift is the skull of a hippopotamus from Nigeria presented by Mrs. Piper. Purchases include a largo collection of South American mammals from Dutch Guiana, and another from Ecuador. The latter is worthy of special mention since it contains a series representing that most interesting genus of Diproto. dont marsupials, Caenolestes. The Dopartment of Mineralogy has received a series of specimens of Darwin glass from Mit. Darwin, Tasmania, collected and urranged by the late Mr. Hartwell Conder and presented by his widow. Darwin glass is a silica glass. Thousands of tons of it in the form of rounded and rod-like pieces are found over an area of sixty square miles in Tasmania. It is believed that the silica-glass was formed by the heat engendered by the impact of a large meteorite. Some crystals of the rare mineral withamite, a pink variety of epidote, have been presented by Mr. W. G. Myers, who found them at the type locality in Glencoe where the new road has cut through the lavas in which withamite occurs. Good crystals of this mineral are rare. A very large rough crystal of microcline feldspar from Norway has been purchased. This crystal measures about $14 \times 12 \times 10$ inches and weighs about 100 pounds.

\section{Report on Abortion}

THE report of the Inter-Departmental Committee on Abortion, which was appointed by the Minister of Health and the Home Secretary under the chairmanship of Mr. Norman Birkett, K.C., has been issued (H.M. Stationery Office. 2s. 6d. net). In the Majority Report, signed by fourteen members, the question of the prevalence of abortion is first examined. They stress the difficulties entailed in arriving at any estimate; but suggest that the number of abortions occurring annually in England and Wales is between 110,000 and 150,000, of which perhaps forty per cent are criminal. The Committee discusses the existing law, analyses the motives for criminal abortion and the methods employed, and examines proposals for amending the law. It recommends that the law should be clarified so as to make it plain that the induction of abortion is legal when the operation is carried out to save the life, or to prevent impairment of health, of the pregnant woman, but expresses strong opposition on ethical, social and medical grounds to any broad relaxation of the law. It is recommended that therapeutic abortions should be notifiable by the operator to the medical officer of health, and that there should be some restriction on the sale of abortifacient drugs. The majority of members of the Committee are not prepared on general grounds to recommend the unrestricted dissemination of birth control advice by the public health services.

\section{The New Radcliffe Observatory}

IN Occasional Notes Roy. Astro. Soc. (No. 4, March 1939), Dr. H. Knox-Shaw gives a very full description of the work on the erection of the 74-inch reflector at Pretoria, and three plates illustrate various parts of the equipment, the turret, the telescope itself as viewed from the north-east, and also the Newtonian observing carriage and the Coude room. It is satisfactory to know that the pyrex disk for the large mirror has been successfully cast and the figuring will be completed in a few months, after which the mirror will be sent to Pasadena for aluminizing. It will be possible to use the telescope at three foci, Newtonian, Cassegrain and Coudé, the focal length in the first case being 30 feet, and the equivalent focal lengths in the last two being $111 \mathrm{ft}$. and $173 \mathrm{ft}$. respectively. The Newtonian focus will bo used for direct photography and the other two for spectroscopic observation. A two-prism spectrograph for use at the Cassegrain focus is under construction and will soon be ready, and a projection measuring machine and also a microphotometer have been made for the Observatory. It is anticipated that the full programmo of the work will be undertaken early in 1910, and the initial programme will include the determination of the radial velocities of the $O$ and $B$ type stars in the portion of the galaxy beyond the reach of the northern observatories. The object of this research is to corroborate present views on galactic rotation. When opportunities occur, photography of the nebule south of $-40^{\circ}$ declination will be undertaken.

\section{Museums and Children}

THE revival of museum efforts which in Great Britain has followed upon the Miers report, has fortunately included in its sweep attempts to increase facilities for the interest and education of the young. But in this aspect of museum work America undoubtedly leads the way, and overyono interested in juvenile education must bo grateful to Miss Ruth Weston for her impressions of American methods which appear as a supplement in the Museums Journal (39, 93, May 1939). Her first impression is one of the bold conception, enterprise, and general 'aliveness' which have produced such museums. Some are special children's museums housed in their own special buildings, in several instances right away from any other museum. Others form sections of larger museums, with special exhibition and other rooms for juveniles, either as an isolated wing or included within the main building. Sometimes the show galleries are supplemented by club rooms, library rooms, reading rooms, and a lecture theatre, which in Boston Children's Museum can seat more than 500. Loan collections of natural history objects for schools and even for individual child borrowers (as at Brooklyn), loan art collections, recording in colour and in black and white the development of art in different periods and countries (like the 2,000 reproductions at Toronto Art Gallery), have become the order of the day in these progressive museums. Much has been done in some British museams, but 